Defining Competitive Sets of Hotel Brands Through Analysis of Customer Brand Switching

\author{
Michael S. Morgan \& Chekitan S. Dev
}

Cornell University

Author Note:

The authors are grateful to John Hauser and Robert Dolan for their helpful comments. 


\begin{abstract}
Identification of a lodging brand's competitive set is a necessary prerequisite to the formulation of effective marketing strategies. The authors use analytical techniques established in empirical studies of consumer packaged goods markets to analyze market share and brand switching. They show, for the first time, that competitive sets of hotel brands can be characterized in terms of consumer characteristics such as usage context and level, post-purchase satisfaction and demographic measures. The implications of the results for the formulation of marketing strategy are discussed.
\end{abstract}




\section{DEFINING COMPETITIVE SETS OF HOTEL BRANDS THROUGH ANALYSIS OF CUSTOMER BRAND SWITCHING}

\section{INTRODUCTION}

It is widely recognized that the strength of a firm's competitive market position is the basis for a sound strategic market plan (cf. Cravens 1991, Jain 1993). Over the last 20 years, there have been a number of studies that have conceptually and empirically investigated the grouping of firms in consumer and industrial markets in order to derive industry structure. Two streams of literature have dominated this effort. In the strategic management literature, the work of Hunt (1972) provided the impetus for studies of “strategic groups” in a number of industries (e.g., Newman 1978, Cool and Shendel 1987, Fiegenbaum and Thomas 1990, Lewis and Thomas 1990). In the marketing literature, the work of Hemiter (1974) and Hendry (1976) provided the impetus for a number of studies that attempted to derive market structure and competition based on brand switching (e.g., Hauser and Wisniewski 1982, Fraser and Bradford 1983, Grover and Srinivasan 1987, Jain et al. 1990, Bucklin and Srinivasan 1991). The focus of our effort is to unite and extend these two streams of literature in an application to the hotel industry. In doing so, we hope to improve our understanding of the concept that lies at the intersection: competitive sets of hotel brands.

\section{BACKGROUND}

Frequently purchased consumer packaged goods markets have provided marketing scholars in recent years with an abundant source of descriptive data on household purchase behavior to derive market structure. This is because reliable scanner data on multiple purchases 
by a large number of households are available for academic research and are fertile ground for building and testing theories of consumer behavior and marketing strategy. Other product genres, such as consumer durables and consumer services, have not afforded the same data opportunities and thus have not been studied at the same level of empirical detail. While some of the information that scanner panels yield is obtainable for these other types of consumer markets through purchase recall surveys, such surveys involve higher data collection costs and loss of reliability due to recall errors and observer effects (Cooper and Nakanishi 1988, Chapter 4).

Carefully designed survey research can produce the same types of results as those which come from the study of scanner data for a consumer packaged goods market. These results include brand switching patterns, purchase frequency and price elasticities (Bucklin and Srinivasan 1991). Some of the variables that consumer researchers might ideally like to measure, such as post-purchase satisfaction and product usage situations or context, are measurable only through surveys. Ideally, these variables would be included in the type of study conducted by Bucklin and Srinivasan.

In studies of strategic groups (see McGee and Thomas 1986, and Thomas and Venkatraman 1988, for a review), the method used to derive these groups is almost exclusively limited to "supply-side" indices: finan cial and operating ratios. In an assessment of this methodology, Cool and Dierickx (1993) comment:

[Strategic group theorists] assume that the different sets of firms compete for the same customers. If markets are segmented, strategic group structure matters only to the extent that different strategic groups target the same market segments, (p. 49) 
Therefore, in segmented markets where different groups of firms are targeting different segments, we need a method of deriving segment specific strategic groups or competitive sets that are customer or user based. After all, the ultimate judge of the competitive set is the customer that chooses one brand over the other under similar circumstances (Cravens 1991).

In this paper, we pursue the possibility of combining market structure analysis-through survey data on reported usage-with broader variables such as demographics and attitude measures to derive competitive sets. This allows, among other things, analysis of brand switching segments (corresponding to brand set partitions-see Bass 1974, Grover and Srinivasan 1987 and Jain et al.1990) in terms of broader consumer characteristics; and, as discussed above, our approach provides some "face validity" support for these methods of brand switching-based competitive set analysis.

We extend the current marketing and strategic management literature by showing that brand switching segment-partitions or strategic groups can be characterized in terms of competitive sets corresponding to market segments derived on the basis of price tier, usage levels, satisfaction ratings, the amount of total switching and demographic characteristics. We extend the hospitality marketing literature by showing that existing techniques for analyzing consumer packaged goods markets can be used to illuminate how hotel chains compete with one another.

We intend for this contribution to (a) help stimulate further empirical research on hospitality market structures and (b) to enable hospitality managers to apply the methods used here to develop competitive marketing strategy. 


\section{BRAND SWITCHING AND MARKET PARTITIONING STUDIES}

In this paper, we apply a variant of one of the state-of-the-art market partitioning methods

to derive competitive sets in the lodging industry. It is helpful to review briefly some of the early motivations for finding and studying market "switching segments" in the marketing literature and "strategic groups" in the strategic management literature.

Bass (1974) first theorized that, given interbrand switching as a significant phenomenon in consumer markets, brand subsets (partitions) of any such market could be defined in terms of which subsets were chosen and switched among by which buyer population groups. These multiple-brand "switching segments" were, for analytical convenience, grouped back together in Bass's derivation of the theory of stochastic brand choice. Methods of partitioning markets into mutually exclusive sets of alternatives — in which within-set switching was higher than across-set switching-were developed by Hemiter (1974) and Hendry (1976). These methods are described in Rubinson et al. (1980).

Market structure analysis based on interbrand switching has been pursued by a number of authors, including Hauser and Wisniewski (1982), Fraser and Bradford (1983), Grover and Srinivasan (1987) and Jain et al. (1990). Methods for “decomposing” market structure from measures of interbrand substitutability (such as switching proportions) vary, but currently in favor are those which employ latent structure analysis (see also Clogg 1971 and Arabie et al. 1981). The easiest and most convenient latent structure application is to factor analyze the (unconditional) brand switching matrix ${ }^{1}$ and interpret the brand-specific loadings for the extracted factors in terms of market structure. High positive loadings (in excess of, say, .4) on the brands within a factor can normally be taken to indicate that these brands belong to the same competitive set (strong negative loadings seem to be rare in this type of analysis, and we did not 
observe any in our applications). A persistent problem with this type of market structure analysis approach, however, is how to identify specific consumers and consumer characteristics (either deterministically or probabilistically) with the brand sets recovered from latent structure analysis. The solution to the problem which we propose here is to group brand purchases, instead of consumers, according to brand set. This approach is described in more detail in the section on data analysis.

\section{STRATEGIC GROUP STUDIES}

To define “strategic groups,” we use Porter’s (1980) definition as a "group of firms in an industry following the same or similar strategy along the strategic dimensions” (p. 129). His list of dimensions incorporates marketing mix (4 P's), but also includes several variables which characterize firms product scope, diversification and technologies. The ensuing empirical literature has stressed the latter, "supply side” characteristics of strategic groups (e.g., Fiegenbaum and Thomas 1990; McGee et al. 1989). This orientation has been cited as a key weakness by Nayyar (1989) in that demand-side variables (e.g., profiling market segments served by a strategic group of firms) are typically ignored. In an attempt to respond to this, our study derives strategic groups on the basis of brand switching. We assess the fit between strategic group theory and brand set partitions derived from consumer switching behavior in more detail in the discussion section.

\section{THE CONTEXT}

Travel and tourism is the world's largest industry comprising of 15 related businesses including airlines, railroads, lodging, restaurants, cruise lines, car rental firms, travel agents and 
tour operators. This “industry” generated \$2.5 trillion in gross output in 1989, employing about 112 million people (World Travel and Tourism Council 1991). The lodging industry, ${ }^{2}$ an integral component of the tourism industry, generated over $\$ 50$ billion in sales in the same period (American Hotel and Motel Association 1992).

In a recent report on competitive strategies for the international hotel industry, market segmentation, positioning and branding were identified as key issues for the future. The report indicated that, because of a general industry slowdown, a greater emphasis is now being placed on better selection and targeting of market segments and on brand identification and positioning with respect to one's relevant competitive set or strategic group (The Economist Intelligence Unit 1991).

The context for this study is the U. S. hotel industry. This industry was selected for two chief reasons. First, it represents a substantial segment of the economy generating $\$ 40$ billion in sales, employing about 1.64 million people (American Hotel and Motel Association 1991). Second, the hotel industry faces varying amounts of environmental uncertainty with nationwide capacity utilization (occupancy) at 61\%, aggregate industry losses in excess of $\$ 2.7$ billion, with 60\% of all hotels operating at a loss (Yoshihashi 1992).

\section{DATA AND RESEARCH STRATEGY}

Our data were obtained through six monthly national sample surveys of National Family Organization (NFO) households. ${ }^{3}$ One respondent from each household was asked to report information on his or her lodging stays ${ }^{4}$ over the previous three months. The response rates from eligible respondents ranged between $65 \%$ and $70 \%$. 
Respondents were included in the data base for this study only if they reported at least two lodging stays in the previous three month period. Further, only stays with one or more of the top 10 market share lodging brands were included in the Final sample. The reason for these screening criteria is that we needed to construct brand switching matrices (see Bass and Parsons 1980) for the leisure and business lodging stay markets which include only a small number of lodging brands. Construction of such matrices requires counting either lodging brand switches or repeat stays for each respondent. Unless a respondent reports at least two consecutive stays, he or she cannot be included in such an analysis. Also, if many brands are included, the cell frequency counts become too small to produce a stable latent class analysis solution (see Appendix).

These screening principles favor inclusion of heavier users of national brands over lighter users and users of non-chain affiliated facilities. When we compared the final sample produced to the excluded pool of respondents reporting only one stay or stays other than with the top 10 share brands, we found several significant differences in background variable measures, especially those related to income, education and product class usage. Thus, our generalizations are based only on the characteristics of the final sample, which on average can be said to purchase lodging stays eight or more times per year. The final sample contained 1464 business stays reported by 832 respondents and 883 leisure stays reported by 622 respondents.

For each respondent-stay, the following variables were measured:

1. Lodging brand used (listed in date order).

2. Purpose of lodging stays. These were reported either as one of ten "business stay" purposes such as convention attendance or as one of nine "leisure stay" purposes such as family vacation. Multi-purpose lodging stays were assigned to the category associated with their "major" purpose. 
3. Characteristics of each stay reported, including number of days stayed, room price paid, a price/value rating and overall satisfaction rating of the lodging brand, and whether or not the current stay constituted a change of lodging brand from the previous stay.

4. Characteristics of the respondent reporting each stay. These characteristics include number of business or leisure travel nights spent during the last 12 months in paid accommodations, age level (reported on a 1-5 scale), male and female head of household education level (1-7 scale), household income level (1-24 scale), household size (1-8 scale), and gender.

Of the 10 brands used in the study, 8 are U. S. owned and one each is owned by the U. K. (Holiday Inn) and French (Motel 6) companies.

\section{DATA ANALYSIS METHODOLOGY}

The procedures for constructing the lodging brand switching matrices for the business and leisure markets, deriving latent market segments from these matrices, assigning respondent stays to latent classes and summarizing stay and respondent characteristics are given in the Appendix. The general approach has been applied to switching data in a consumer products market by Grover and Srinivasan (1987) and by Jain, Bass and Chen (1990). The reader is referred to these papers as well for further technical details on the data analysis procedure used here.

It is important to note three important assumptions here. The first is that the buyer's total number of lodging stays is independent of his/her choice probabilities of choosing particular brands. This is an assumption which is typical in stochastic brand choice theory-see Bass 1974. 
The second is that within market segments-that is, as defined by latent classes derived from the switching data-the probability of choosing a given lodging brand is independent of the previous choice (also called the "zero order assumption"-see Bass 1974). One way of viewing this is that a consumer who purchases from a given set of brands is not likely to switch among them based on what he or she experiences on each stay. Rather, consumers know what to expect from, and are satisfied with, all of the brands in their restricted choice set about equally. The third assumption is that summarizing results in terms of "respondent-stays" provides more useful information instead of summarizing by respondents. The reason for this is to account for respondents' reporting multiple stays. Examining the data at the level of the individual stay relieves us of having to aggregate over all stay characteristics for a given respondent On the other hand, this focusses on the "market of stay occasions" rather than the market of buyers, which is an important distinction from person-based approaches to segmentation and positioning. See Kamakura and Russell (1989) and the Appendix for further discussion of this theoretical distinction.

\section{RESULTS}

As explained in the Appendix, we were able to derive a four-class solution for the business market and a three-class solution for the leisure market. Each of these latent class solutions is the "best fitting" portrayal of market segments and purchases of lodging brands by each segment.

Each latent class itself represents a given market segment as well as the brands generally purchased by that segment. Thus, we call the latent classes "brand/segments" in what follows (see also Grover and Srinivasan 1987). The latent class probabilities represent the share of the 
total market purchased by each brand/segment. Within a brand/segment, the proportion of stays allocated to each brand can also be derived. Table 1 shows the results of this analysis for each market

The results of the latent class solutions provide some interesting information on competitive sets in the lodging industry. First, it is important to note that competitive set definition depends, to some extent, cm purchase occasion or, in this case, purpose of visit. For example, while Holiday Inn and Ramada compete directly for the business traveler market, Holiday Inn is competing primarily with Marriott, Hilton, Sheraton and Hyatt for the leisure traveler market. Second, brands belonging to more than one competitive set could mean some confusion regarding product positioning. For business travel, while Hyatt, Motel 6, and Super 8 belong to only one business and one leisure category (perhaps more clearly positioned), the other seven brands belong to two competitive sets. In the leisure travel group, eight of the 10 brands belong to one competitive set, while two (Holiday Inn and Best Western) belong to two each. Thus, two possible strategic implications can be derived from this table. First, finding out which brand(s) you're competing with, from the consumers’ purchase behavior, is a necessary first step in formulation of competitive marketing strategies. Second, the degree of clarity of a brand's positioning, in terms of membership in one competitive set or a number of competitive sets, is one assessment of the brand's overall positioning clarity.

For each latent class solution, each market segment can be further described in terms of the purposes of the lodging stays and in what frequencies they occur (Table 2), gender proportions of each segment (Table 3), sociodemographic characteristics of the respondents weighted by number of stays reported (Table 4), and characteristics of stays reported, including 
the room price, number of days stayed, and stay satisfaction ratings (Table 5). These are reported below.

Where possible, statistical tests of the mean differences between market segments on these measures are shown in the tables. We applied one-tail, two-mean Z-tests to each mean variable between all possible segment mean pairs to test whether these ordered relationships are statistically significant.

The results of the customer profile for each competitive set provides strategically useful information for target marketing and development of marketing programs. For example, the data presented in Tables 1-5 suggest that business travel related competitive group 1 is made up of mostly first-class hotels that cater to the conference/meeting attending, mostly male, middle aged, educated, middle income, two person household, infrequent traveler, variety seeking, generally satisfied customer. Teachers and white collar professionals are potential market segments for this competitive set. Competitive group 2 on the other hand is made up of mid-scale hotels catering primarily to the salesman/consultant, modest education, middle income, three person household, regular traveler, brand loyal, finicky customer. Group 3 is made up of a mix of upscale and midscale hotels catering to the saleswoman/consultant, highly educated, affluent, two person household, frequent traveler, long staying, moderately loyal, generally satisfied customer. Group 4 is made up of economy hotels that cater to the sales/stopover traveler, mostly male, older, less educated, lower income, larger household, infrequent traveler, frequent switcher, less satisfied customer. Each of the four brand/segments suggest specific marketing strategies that are likely to be successful based on the market profile. The purchase decision for business brand/segment is probably predetermined by the conference/meeting organizers. Consequently, the “influencer” needs to be targeted to generate business. Few brand/segment 2, 
consistency of accommodations and loyalty rewards (frequent guest awards) are probably key considerations. For brand/segment 3, services and security are probably paramount considerations in choosing a hotel. For brand/segment 4, a "deal” and basic facilities are likely to motivate a purchase decision.

A similar analysis can be conducted for the three competitive sets identified for the leisure travelers. The categories in this are fairly clear cut with mostly first class hotels in the first set, midscale hotels in the second, and economy hotels in the third. The differences among the three brand/ segments are not as marked as in the business category. Group 1 represents a younger group, on a short getaway, visiting family/friends type of trip customer. Group 2 is a more traditional, vacation oriented, mostly male, older, less educated customer. The only variable that separates Group 3 from the others is a higher propensity to switch, perhaps related to their patronage of lower price hotels. Specific marketing strategies few these three brand segments could include getaway weekend packages for the first group, all inclusive value package vacations for the second, and off-season low price deals for the third.

In this paper we have implemented an established method few analyzing market share and brand switching responses within a service market-the lodging industry. Specifically, we have done the following:

1. Calculated latent market brand/segments, along with within-class values for market share for the top 10 share lodging brands. Using this type of analysis, interbrand competitive strengths and positioning can be quantified and compared.

2. Shown that competitive sets can and do vary according to consumer- based measures such as usage context, usage level, price paid, post-purchase satisfaction and various demographic measures. This, to our knowledge, is the first time these relationships 
have been drawn among latent brand/segments, not only for a service, but for any product class.

\section{DISCUSSION}

In chapter 7 of Competitive Strategy, Porter (1980) discusses how the market structure of an industry forms $\mathrm{cm}$ the basis of dimensions such as brand identification, product quality and price positioning. This results in a "mapping” of the industry into strategic groups. Similarly, an analysis of consumer purchase patterns relating to choices among competing brands can provide partitions or brand segments. We have shown here that in the lodging industry, competitive sets can be derived on the basis of brand choices made by different market segments.

The derivation of competitive sets of hotel brands based on brand switching provides us with information that can be utilized in strategically useful ways. Drawing from the findings of our analysis, marketing strategies for individual hotel brands can be formulated. In terms of overall positioning, in business brand/segment 2, Holiday Inn is the clear leader and Ramada is a much smaller player. At the time of this writing, Ramada had a very aggressive television advertising campaign targeted to the business traveler (on CNN) with the slogan: Ramada's In, Holiday's Out. While a discussion of the merits of the actual advertising campaign are beyond the scope of this article, strategically the idea is supported by our analysis.

In addition, brand switching-based competitive sets can be used to formulate specific marketing mix strategies. Identification of key attributes, comparing attributes among competing brands, and new product developments are ways in which this competitive grouping can be used. Super 8 and Motel 6 compete directly for same business and leisure brand/segments. It would follow then, that these two brands should seek to differentiate themselves primarily from each 
other. Price category membership and competitive pricing also depend on the competitive set. While Rama- da competes with Holiday Inn for brand/segment 2, it also competes with Marriott and Hilton for brand/segment 3. This would suggest that, in certain locations, Ramada has the potential to obtain a premium price for its facilities. Competitive sets based on brand switching can also be used to identify segment based benefits to highlight in advertising. Marriott, a major contender for business brand/segment 3, offers fast check-in and speedy room service, key benefits for the upscale, frequent female traveler profiled earlier in brand/segment 3. Distribution strategies can also be formulated based on a combination of competitive set/segment profile information. While they are in the same competitive set, Super 8 has a toll-free number while Motel 6 does not. Additionally, Motel 6 generally charges less than Super 8 (Slogan: The lowest price of any national chain), claiming it is passing on the saving to the customer. While they are similar in size, Motel 6 has twice Super 8's share in the price sensitive leisure brand/segment 3 .

\section{A BROADENED VIEW OF COMPETITIVE ANALYSIS FOR THE HOTEL INDUSTRY}

Strategic management and marketing scholars writing on the subject of competitive analysis have been quite critical of the state-of-the-art as represented in their own streams of literature. In the strategic management literature a number of authors have suggested enriching the current conceptualization of strategic groups to include demand-side variables (Nayyar, 1989), market segment variables (Cool and Dierickx, 1993), and a focus on competitive groups (Reger and Huff, 1993). Earlier we pointed out that scanner data does not provide product usage context or customer satisfaction data to enable us to analyze purchase behavior more meaningfully. In this study we have attempted to extend the streams of literature on strategic groups and market partitions of lodging brands by describing a brand-switching based strategic 
grouping which we are calling competitive sets. Each of the competitive sets derived from the data has a distinct group of brands and a market segment associated with that group. Cognitively, competitive sets can also be thought of as an average customer's post-purchase consideration set; a group of brands from which a customer actually chooses. It is this set of brands that should be used in formulating the basics of a lodging brand's competitive marketing strategy.

\section{LIMITATIONS OF THIS STUDY}

It should be noted that these data do not separate out the effects of lack of availability of a lodging brand at a chosen travel destination. In other words, does a "switch" occur when the traveler wants to switch or when his or her preferred brand is not available (either for lack of locational convenience or available rooms)? Although we cannot, from the available data, derive a purely volitional measure of switching, we argue that our switching partitions are more realistic in that they include the effect of limited availability of some brands while other measures (such as those based on stated preferences) do not. Additional limitations of this study have to do with potential reporting biases in the survey results. As in all survey data, there is the potential for recall error to occur, either through systematic bias (e.g., customers with lower levels of satisfaction might tend to “remember” having paid higher prices) or random inaccuracies (e.g., one lodging stay out of several a respondent has made might be forgotten and hence go unreported). 


\section{DIRECTIONS FOR FUTURE RESEARCH}

We hope that our contribution will stimulate further empirical research among hospitality marketing scholars in the area of competitive analysis. Some potentially fruitful questions include:

A. What different ways are there to handle usage context? We have classified consumers into business and leisure travellers here for illustration. The purposes of lodging stays, however, can be viewed as much more idiosyncratic and allow for much finer distinctions among consumer and purchase types.

B. How do competitive sets change over time? With appropriate replication of the partitioning method, the same lodging brands could be analyzed for a different time period. Results from the analysis of longitudinal data might indicate how competitive positioning changes over time.

C. What are the performance implications of competitive set membership? Based on a definition of high and low performing groups, marketing strategy for repositioning hotel brands can be formulated.

Implicit in questions $\mathrm{B}$ and $\mathrm{C}$ is the issue of how the attributes of hotels might concur within or differ across competitive sets. We have thus far identified only the attribute of price as a differentiating factor. However, even though this factor may covary with many others (e.g., quality of rooms and other facilities) more extensive data on other attributes-both tangible and intangible-would provide a more complete competitive picture. To the extent that customers trade off price for other features, information on these other features would allow hotel marketers 
to generate competitive positions on a true attribute-by-attribute basis, instead of relying exclusively on price image or price discounting (cf. Wind et al. 1989).

There are many fertile areas of future empirical research for this and other hospitalitybased industries. We expect that this study will promote such research, which will eventually provide hospitality marketing scholarship with a strong empirical foundation for the study of competition. 


\section{NOTES}

1. This matrix contains elements (i, j), where the (i, j)th entry contains the number of times a purchase of brand $\mathrm{j}$ follows a purchase of brand i for the same consumer.

2. The term "lodging” here refers to any commercial (i.e., paid-for) overnight accommodations away from home. This can include facilities such as trailer parks and boarding houses. We use this construct rather than "hotels and motels” throughout, to indicate the full range of choices available to travelers.

3. The lodging survey data are collected on an ongoing basis by D. K. Shifflett and Associates as part of their Directions Travel Intelligence System ${ }^{\mathrm{TM}}$. Their system uses an N.F.O. ombudsman survey panel.

4. A "lodging stay" is defined as one purchase of overnight accommodations for one or more nights. A “stay” thus constitutes one brand choice on one purchase occasion. 


\section{REFERENCES}

American Hotel and Motel Association (1991), Lodging Industry Profile, Washington, DC: AH\&MA Communications Department.

American Hotel and Motel Association (1992), Lodging Industry Profile, Washington, DC: AH \& MA Communications Department

Arabie, P., J. D. Carroll, W. DeSarbo and J. Wind (1981), “Overlapping clustering: A new method for product positioning,” Journal of Marketing Research, 18:310-317.

Bass, F. M. (1974), “The theory of stochastic preference and brand switching,” Journal of Marketing Research, 11: 1-20.

, A. Jeuland and G. P. Wright (1976), "Equilibrium stochastic choice and market penetration theories: Derivations and comparisons,” Management Science, 22: 10511063. and T. L. Pilon (1980), “A stochastic brand choice framework for econometric modeling of time senes market share, Journal of Marketing Research, 17:486-497.

Bucklin, R. E. and V. Srinivasan (1991), "Determining interbrand substitutability through survey measurement of consumer preference structures,” Journal of Marketing Research, 28: 5871.

The Economist Intelligence Unit (1991), Competitive Strategies for the International Hotel Industry, Special Report No. 1180, London, UK: The Economist Group.

Cool, K. and I. Dierickx (1993), “Rivalry, strategic groups and firm profitability,” Strategic Management Journal, 14:47-59.

Cooper, L. G. and M. Nakanishi (1988), Market-share analysis: Evaluating competitive marketing effectiveness, Boston: Kluwer Academic Publishers. 
Clogg, C. C. (1981), "Latent structure models of mobility,” American Journal of Sociology, 86: 836-868.

Cravens, D. W. (1991), Strategic Marketing, Homewood, EL: Irwin.

Ehrenberg, A. S. C. (1969), "Towards an integrated theory of consumer behavior: Something for theoreticians to work on and for practical men to think about," Journal of Marketing Research, 11: 305-337. Repeat Buying, Amsterdam: North Holland. , G. J. Goodhardt and T. P. Barwise (1990), “Double jeopardy revisited,” Journal of Marketing, 54: 82-91.

Fiegenbaum, A. and H. Thomas (1990), "Strategic groups and performance: The U.S. insurance industry, 1970-84,” Strategic Management Journal, 11: 197- 215.

Fraser, C. and J. W. Bradford (1983), “Competitive market structure analysis: Principal partitioning of revealed substitutabilities,” Journal of Consumer Research, 10:15-30.

Grover, R. and V. Srinivasan (1987), “A simultaneous approach to market segmentation and market structuring,” Journal of Marketing Research, 24: 139- 153.

Guadagni, P. M. and J. D. C. Little (1983), “A logit model of brand choice calibrated on scanner data,” Marketing Science, 2(3): 203-218.

Hauser, J. R. and K. J. Wisniewski (1982), "Dynamic analysis of consumer response to marketing strategies,” Marketing Science, 2(5): 455-486.

The Hendry Corporation (1976), Speaking of Hendry.

Hemiter, J. (1974), “A comparison of the entropy model and the Hendry model,” Journal of Marketing Research, 11: 21-29. 
Hunt, M. S. (1972), Competition in the major home appliance industry 1960-1970, Unpublished Doctoral Dissertation, Harvard University.

Jain, D., F. M. Bass and Y. M. Chen (1990), “Estimation of latent class models with heterogeneous choice probabilities: An application to market structuring,” Journal of Marketing Research, 27: 94-101.

Jain, S. C. (1993), Marketing Planning \& Strategy, Cincinnati, OH: Southwestern, Kamakura, W. A. and G. J. Russell (1989), “A probabilistic choice model for market segmentation and elasticity structure,” Journal of Marketing Research, 26: 379-90.

Kahn, B. E, M. U. Kalwani and D. G. Morrison, (1987), “Using purchase frequencies and penetration rates to infer brand positionings: Niching versus change-of-pace,” working paper, John E Anderson, Graduate School of Management, U. C. L. A.

Kalwani, M. U. and D. G. Morrison (1977), “A parsimonious description of the Hendry system,” Management Science, 23:467-477.

Lewis, P. and H. Thomas (1990), “The linkage between strategy, strategic groups, and performance in the U.K. retail grocery industry,” Strategic Management Journal, 11: 197-215.

McFadden, D. (1970), “Conditional logit analysis of qualitative choice behavior,” Frontiers of Econometrics, Paul Zarembk (ed.), New York: Academic Press, Inc., 105-142.

McGee, D. O., P. R. Varadarajan, and W. M. Pride (1989), "Strategic adaptability and firm performance: A market-contingent perspective,” Journal of Marketing, 53: 21-35.

Nayyar, P. (1989), “Strategic groups: A comment,” Strategic Management Journal, 10: 101-103. Newman, H. H. (1978), “Strategic groups and structure/performance relationships,” Review of Economics and Statistics, 60:417-427. 
Porter, M. E. (1980), Competitive Strategy: Techniques for Analyzing Industries and Competitors, New York: The Free Press.

Rubinson, J. R., W. F. Vanhonacker and F. M. Bass (1980), “A note on 'A parsimonious description of the Hendry system,'” Management Science, 26: 215-226.

Saunders, D. R. (1960), “A computer program to find the best fitting orthogonal factors for a given hypothesis,” Psychometrika, 25: 207-210.

Thomas, H. and H. Venkatraman (1988), "Research on strategic groups: progress and prognosis," Journal of Management Studies, 25: 537-55.

World Travel and Tourism Council (1991), "The WTTC Report: Travel and Tourism in the World Economy,” Washington, DC: WTTC.

Wittink, D. R. (1977), “Exploring territorial differences in the relationship between marketing variables,” Journal of Marketing Research, 14:145-55.

Yoshihashi, P. (1992), “Hotel recovery will be a late arrival,” The Wall Street Journal, (July 27), Bl. 
Table 1. Latent class (brand/segment) solutions for each market.

Business only segments

Estimated latent

cass probabilities:

Holiday Inn
Best Western
Days Inns
Marriott
Hilton
Motel 6
Sheraton
Ramada
Super 8
Hyatt

Leisure only segments

Estimated latent class probabilities:

Best Westem

Days Inns

Marriott

Hilton

Motel 6

Sheraton

Ramada

Super 8

Hyatt
Brand/segment

\begin{tabular}{crrrrr}
1 & 2 & 3 & 4 & \\
& & & & \\
0.161 & 0.467 & 0.245 & 0.128 & \\
\multicolumn{7}{c}{ Actual aggregate } \\
mithin-class market shares: & $\begin{array}{c} \\
\text { market share }\end{array}$ \\
0.00 & 0.68 & 0.26 & 0.00 & .382 \\
0.00 & 0.07 & 0.00 & 0.45 & .101 \\
0.05 & 0.11 & 0.00 & 0.00 & .062 \\
0.24 & 0.00 & 0.45 & 0.00 & .134 \\
0.18 & 0.00 & 0.27 & 0.00 & .092 \\
0.00 & 0.00 & 0.00 & 0.33 & .038 \\
0.31 & 0.05 & 0.00 & 0.00 & .063 \\
0.00 & 0.09 & 0.03 & 0.00 & .051 \\
0.00 & 0.00 & 0.00 & 0.22 & .033 \\
0.22 & 0.00 & 0.00 & 0.00 & .045
\end{tabular}

Brand/segment

123

$\begin{array}{lll}0.243 & 0.495 & 0.262\end{array}$

Estimated

within-class market shares:

Actual

market share

$\begin{array}{lll}0.59 & 0.23 & 0.00 \\ 0.00 & 0.38 & 0.11 \\ 0.00 & 0.28 & 0.00 \\ 0.14 & 0.00 & 0.00 \\ 0.13 & 0.00 & 0.00 \\ 0.00 & 0.00 & 0.60 \\ 0.10 & 0.03 & 0.00 \\ 0.00 & 0.08 & 0.00 \\ 0.00 & 0.00 & 0.29 \\ 0.04 & 0.00 & 0.00\end{array}$

0.265

0.201

0.133

0.048

0.053

0.129

0.033

0.049

0.078

0.011 
Table 2. Purpose of travel for each market.

Business only brand/segments

$\begin{array}{lrrrrrrrr}\begin{array}{l}\text { Purpose of } \\ \text { travel }\end{array} & \begin{array}{r}1 \\ \text { freq }\end{array} & \% & \begin{array}{r}2 \\ \text { freq }\end{array} & \% & \text { treq } & \% & \text { treq } & \% \\ \begin{array}{l}\text { convention } \\ \text { seminar/training }\end{array} & 41 & 17.7 & 22 & 3.8 & 21 & 7.0 & 9 & 5.7 \\ \text { other group mtg. } & 29 & 12.6 & 68 & 11.7 & 45 & 14.9 & 17 & 10.8 \\ \text { sales } & 29 & 12.6 & 39 & 6.7 & 26 & 8.6 & 7 & 4.5 \\ \text { consulting } & 31 & 13.4 & 94 & 16.1 & 79 & 26.2 & 27 & 17.2 \\ \text { repair/service } & 30 & 13.0 & 71 & 12.2 & 53 & 17.5 & 11 & 7.0 \\ \text { government/military } & 1 & 0.4 & 64 & 11.0 & 11 & 3.6 & 5 & 3.2 \\ \text { stopover in route } & 20 & 8.7 & 62 & 10.6 & 15 & 5.0 & 6 & 3.8 \\ \text { other business } & 10 & 4.3 & 53 & 9.1 & 12 & 4.0 & 52 & 33.1 \\ \text { job change } & 39 & 16.9 & 91 & 15.6 & 34 & 11.3 & 13 & 8.3 \\ & 1 & 0.4 & 19 & 3.3 & 6 & 2.0 & 10 & 6.4\end{array}$

Leisure only brand/segments

$\begin{array}{lrrrrrr}\begin{array}{l}\text { Purpose of } \\ \text { travel }\end{array} & \begin{array}{r}1 \\ \text { freq }\end{array} & \% & \begin{array}{r}2 \\ \text { treq }\end{array} & \% & \begin{array}{r}3 \\ \text { treq }\end{array} & \% \\ \begin{array}{l}\text { camping } \\ \text { group tour }\end{array} & 1 & 0.3 & 3 & 0.8 & 9 & 5.2 \\ \text { group function } & 14 & 4.4 & 28 & 7.9 & 9 & 5.2 \\ \text { special event } & 53 & 16.5 & 28 & 7.9 & 11 & 6.4 \\ \text { getaway weekend } & 55 & 17.1 & 40 & 11.2 & 26 & 15 \\ \text { see friends/relatives } & 51 & 15.9 & 51 & 14.3 & 64 & 37 \\ \text { general vacation } & 84 & 26.2 & 121 & 34 & 49 & 28.3 \\ \text { stopover in route } & 52 & 16.2 & 75 & 21.1 & 5 & 2.9 \\ \text { personal business } & 11 & 3.4 & 10 & 2.8 & 12 & 4 \\ & 39 & 16.9 & 91 & 15.6 & 34 & 11.3\end{array}$


Table 3. Gender differences by brand/segment.

$\begin{array}{lrrrrrrrrr}\text { Business only brand/segments } & \begin{array}{r}1 \\ \text { Gender }\end{array} & \text { treq } & \% & \text { freq } & \% & \begin{array}{r}3 \\ \text { treq }\end{array} & \% & \text { treq } & \% \\ \text { Male } & 180 & 79.6 & 470 & 83.2 & 153 & 44.6 & 108 & 72.0 \\ \text { Female } & 46 & 20.4 & 95 & 16.8 & 190 & 55.4 & 42 & 28.0 \\ \text { Leisure only brand/segments } & & & & & & & & \\ & 1 & & & & & & \\ \text { Gender } & \text { treq } & \% & \text { treq } & \% & \text { treq } & \% & \\ \text { Male } & 155 & 49.7 & 470 & 83.2 & 87 & 53.0 & \\ \text { Female } & 157 & 50.3 & 95 & 16.8 & 77 & 47.0 & \end{array}$


Table 4. Sociodemographic differences.

Business only brand/segments

\begin{tabular}{|c|c|c|c|c|c|c|}
\hline & & \multicolumn{4}{|c|}{ Brand/segment } & \multirow{2}{*}{$\begin{array}{l}\text { group means' } z \\
\text { signt. at } p<.01\end{array}$} \\
\hline & & 1 & $\begin{array}{c}\text { Brand } \\
2\end{array}$ & nent 3 & 4 & \\
\hline $\begin{array}{l}\text { Age level } \\
(1-5)\end{array}$ & $\begin{array}{r}\mathbf{N} \\
\text { mean } \\
\mathbf{s . d .} \\
\text { median } \\
\text { mode }\end{array}$ & $\begin{array}{c}231 \\
2.55 \\
(1.18) \\
2 \\
2\end{array}$ & $\begin{array}{c}583 \\
2.53 \\
(1.13) \\
2 \\
2\end{array}$ & $\begin{array}{c}302 \\
2.50 \\
(1.13) \\
2 \\
2\end{array}$ & $\begin{array}{c}157 \\
2.78 \\
(1.23) \\
3 \\
3\end{array}$ & 3,4 \\
\hline $\begin{array}{l}\text { Male HH } \\
\text { education } \\
\text { level } \\
(1-7)\end{array}$ & $\begin{array}{r}\mathrm{N} \\
\text { mean } \\
\mathbf{s . d} . \\
\text { median } \\
\text { mode }\end{array}$ & $\begin{array}{c}198 \\
5.89 \\
(1.07) \\
6 \\
7\end{array}$ & $\begin{array}{c}527 \\
5.62 \\
(1.11) \\
6 \\
6\end{array}$ & $\begin{array}{c}261 \\
6.18 \\
(0.93) \\
6 \\
7\end{array}$ & $\begin{array}{c}134 \\
5.45 \\
(1.40) \\
5 \\
7\end{array}$ & $\begin{array}{l}1,2 \\
1,3 \\
1,4 \\
2,3 \\
3,4\end{array}$ \\
\hline $\begin{array}{l}\text { Female HH } \\
\text { education } \\
\text { level } \\
(1-7)\end{array}$ & $\begin{array}{r}\mathrm{N} \\
\text { mean } \\
\mathbf{s . d} . \\
\text { median } \\
\text { mode }\end{array}$ & $\begin{array}{c}191 \\
5.49 \\
(1.10) \\
5 \\
5\end{array}$ & $\begin{array}{c}475 \\
5.23 \\
(1.15) \\
5 \\
5\end{array}$ & $\begin{array}{c}239 \\
5.62 \\
(1.07) \\
6 \\
5\end{array}$ & $\begin{array}{r}142 \\
4.94 \\
(1.14) \\
5 \\
4\end{array}$ & all \\
\hline $\begin{array}{l}\text { Househoid } \\
\text { lncome } \\
\text { level } \\
(1-24)\end{array}$ & $\begin{array}{r}\mathbf{N} \\
\text { mean } \\
\mathbf{s . d} \\
\text { median } \\
\text { mode }\end{array}$ & $\begin{array}{c}174 \\
14.90 \\
(5.69) \\
16.5 \\
18\end{array}$ & $\begin{array}{c}505 \\
14.22 \\
(5.35) \\
16 \\
16\end{array}$ & $\begin{array}{c}236 \\
16.59 \\
(5.21) \\
18 \\
18\end{array}$ & $\begin{array}{c}130 \\
14.31 \\
(4.80) \\
15 \\
15\end{array}$ & $\begin{array}{l}1,3 \\
2,3 \\
3,4\end{array}$ \\
\hline $\begin{array}{l}\text { Household } \\
\text { size } \\
(1-8)\end{array}$ & $\begin{array}{r}\mathrm{N} \\
\text { mean } \\
\mathbf{s . d} . \\
\text { median } \\
\text { mode }\end{array}$ & $\begin{array}{c}204 \\
2.43 \\
(1.18) \\
2 \\
2\end{array}$ & $\begin{array}{r}555 \\
2.74 \\
(1.32) \\
3 \\
2\end{array}$ & $\begin{array}{c}263 \\
2.37 \\
(1.29) \\
2 \\
2\end{array}$ & $\begin{array}{c}125 \\
2.90 \\
(1.38) \\
3 \\
2\end{array}$ & $\begin{array}{l}1,2 \\
1,4 \\
2,3 \\
3,4\end{array}$ \\
\hline \multicolumn{7}{|c|}{ Leisure only brand/segments } \\
\hline $\begin{array}{l}\text { Age } \\
\text { level } \\
(1-5)\end{array}$ & $\begin{array}{r}\mathrm{N} \\
\text { mean } \\
\mathbf{s . d .} \\
\text { median } \\
\text { mode }\end{array}$ & $\begin{array}{c}321 \\
2.70 \\
(1.34) \\
2 \\
1.5\end{array}$ & $\begin{array}{r}356 \\
3.07 \\
(1.45) \\
3 \\
5\end{array}$ & $\begin{array}{c}173 \\
2.74 \\
(1.39) \\
3 \\
1.5\end{array}$ & & $\begin{array}{l}1,2 \\
2,3\end{array}$ \\
\hline $\begin{array}{l}\text { Male HH } \\
\text { education } \\
\text { level } \\
(1-7)\end{array}$ & $\begin{array}{r}\mathrm{N} \\
\text { mean } \\
\mathrm{s.d} . \\
\text { median } \\
\text { mode }\end{array}$ & $\begin{array}{c}251 \\
5.49 \\
(1.31) \\
6 \\
7\end{array}$ & $\begin{array}{c}284 \\
5.21 \\
(1.33) \\
5 \\
4\end{array}$ & $\begin{array}{c}144 \\
5.32 \\
(1.38) \\
5 \\
5\end{array}$ & & 1,2 \\
\hline
\end{tabular}


Table 4 con't

Leisure only brand/segments

$\begin{array}{lr}\text { Female HH } & \mathrm{N} \\ \text { education } & \text { mean } \\ \text { level } & \text { s.d. } \\ (1-7) & \text { median } \\ & \text { mode }\end{array}$

Household

Income

level

$(1-24)$

Household

size

(1-8)

$N$
mean
s.d.
median
mode

N

mean

s.d.

median

mode
1

\section{$2_{3}^{\text {Brand/segment }}$}

3

272

5.28

(1.16)

5
5

265

13.84

(5.75)

15

17

287

2.39

(1.17)

2
318

4.91

(1.21)

5
4

313

12.90

(5.92)

15

16

335

2.57

(1.15)

2
2

2
(1.17)

5
5

157

13.24

(5.37)

15
18

143

2.37

(1.15)

2 group means' $z$ signt. at $\mathrm{p}<.01$

1,2

1,3 
Table 5. Stay/product class usage characteristics.

Business only brand/segments

Brand/segments

group means' z signt. at $p<.01$

\begin{tabular}{|c|c|c|c|c|c|c|}
\hline & & 1 & 2 & 3 & 4 & \\
\hline $\begin{array}{l}\text { Number of } \\
\text { business } \\
\text { nights/yr }\end{array}$ & $\begin{array}{r}\mathrm{N} \\
\text { mean } \\
\text { s.d. } \\
\text { median } \\
\text { mode }\end{array}$ & $\begin{array}{r}168 \\
34.67 \\
(38.07) \\
23 \\
30\end{array}$ & $\begin{array}{c}310 \\
42.03 \\
(42.67) \\
28 \\
20\end{array}$ & $\begin{array}{r}170 \\
45.65 \\
(43.72) \\
30 \\
30\end{array}$ & $\begin{array}{c}73 \\
40.52 \\
(48.41) \\
25 \\
25\end{array}$ & $\begin{array}{l}1,2 \\
1,3 \\
3,4\end{array}$ \\
\hline $\begin{array}{l}\text { Number of } \\
\text { leisure } \\
\text { nights/yr }\end{array}$ & $\begin{array}{r}\mathrm{N} \\
\text { mean } \\
\text { s.d. } \\
\text { median } \\
\text { mode }\end{array}$ & $\begin{array}{c}143 \\
10.86 \\
(9.31) \\
10 \\
10\end{array}$ & $\begin{array}{c}267 \\
9.73 \\
(9.63) \\
8 \\
10\end{array}$ & $\begin{array}{c}147 \\
10.80 \\
(9.06) \\
10 \\
10\end{array}$ & $\begin{array}{c}77 \\
9.52 \\
(6.11) \\
8 \\
8\end{array}$ & 3,4 \\
\hline $\begin{array}{l}\text { Number of } \\
\text { trips } \\
\text { this stay }\end{array}$ & $\begin{array}{r}\mathrm{N} \\
\text { mean } \\
\mathrm{s.d} . \\
\text { median } \\
\text { mode }\end{array}$ & $\begin{array}{c}231 \\
3.19 \\
(1.74) \\
3 \\
2\end{array}$ & $\begin{array}{c}583 \\
3.29 \\
(1.94) \\
3 \\
2\end{array}$ & $\begin{array}{c}302 \\
3.57 \\
(2.01) \\
3 \\
2\end{array}$ & $\begin{array}{r}157 \\
3.08 \\
(2.07) \\
2 \\
2\end{array}$ & $\begin{array}{l}1,3 \\
3,4\end{array}$ \\
\hline $\begin{array}{l}\text { Number of } \\
\text { days } \\
\text { stayed }\end{array}$ & $\begin{array}{r}\mathrm{N} \\
\text { mean } \\
\mathrm{s}, \mathrm{d} . \\
\text { median } \\
\text { mode }\end{array}$ & $\begin{array}{c}226 \\
2.62 \\
(1.96) \\
2 \\
1\end{array}$ & $\begin{array}{c}533 \\
2.55 \\
(3.09) \\
2 \\
1\end{array}$ & $\begin{array}{c}286 \\
2.35 \\
(2.05) \\
2 \\
1\end{array}$ & $\begin{array}{c}148 \\
2.32 \\
(3.58) \\
1 \\
1\end{array}$ & \\
\hline $\begin{array}{l}\text { Room } \\
\text { Price } \\
\text { (\$) }\end{array}$ & $\begin{array}{r}\mathrm{N} \\
\text { mean } \\
\mathrm{s.d} \\
\text { median } \\
\text { mode }\end{array}$ & $\begin{array}{c}205 \\
86.89 \\
(54.31) \\
79 \\
90\end{array}$ & $\begin{array}{c}514 \\
56.90 \\
(20.43) \\
55 \\
50\end{array}$ & $\begin{array}{c}265 \\
91.09 \\
(46.20) \\
85 \\
60\end{array}$ & $\begin{array}{r}147 \\
37.41 \\
(13.03) \\
35 \\
30\end{array}$ & $\begin{array}{l}1,2 \\
1,4 \\
2,3 \\
2,4 \\
3,4\end{array}$ \\
\hline $\begin{array}{l}\text { Percent } \\
\text { resp. } \\
\text { switching }\end{array}$ & $\begin{array}{r}\mathrm{N} \\
\text { mean } \\
\mathrm{s.d} \\
\text { median } \\
\text { mode }\end{array}$ & $\begin{array}{c}231 \\
0.78 \\
(0.41) \\
1 \\
1\end{array}$ & $\begin{array}{r}583 \\
0.34 \\
(0.47) \\
0 \\
0\end{array}$ & $\begin{array}{c}302 \\
0.53 \\
(0.50) \\
1 \\
1\end{array}$ & $\begin{array}{c}157 \\
0.12 \\
(0.33) \\
0 \\
0\end{array}$ & all \\
\hline $\begin{array}{l}\text { Overall } \\
\text { satisf. } \\
(1-10)\end{array}$ & $\begin{array}{r}\mathrm{N} \\
\text { mean } \\
\mathbf{s . d} . \\
\text { median } \\
\text { mode }\end{array}$ & $\begin{array}{c}231 \\
7.40 \\
(1.98) \\
8 \\
8\end{array}$ & $\begin{array}{r}581 \\
6.77 \\
(1.91) \\
7 \\
8\end{array}$ & $\begin{array}{c}301 \\
7.37 \\
(1.77) \\
8 \\
8\end{array}$ & $\begin{array}{c}157 \\
6.90 \\
(1.82) \\
7 \\
7\end{array}$ & $\begin{array}{l}1,2 \\
1,4 \\
2,3 \\
3,4\end{array}$ \\
\hline $\begin{array}{l}\text { Satisf. } \\
\text { with } \\
\text { value } \\
(1-10)\end{array}$ & $\begin{array}{r}\mathrm{N} \\
\text { mean } \\
\mathrm{s.d} . \\
\text { median } \\
\text { mode }\end{array}$ & $\begin{array}{r}114 \\
6.96 \\
(2.06) \\
7 \\
8\end{array}$ & $\begin{array}{c}268 \\
6.61 \\
(2.12) \\
7 \\
5\end{array}$ & $\begin{array}{c}109 \\
6.93 \\
(2.16) \\
7 \\
8\end{array}$ & $\begin{array}{r}69 \\
6.74 \\
(2.26) \\
7 \\
6\end{array}$ & \\
\hline
\end{tabular}


Table 5 con't

Leisure only brand/segments

\begin{tabular}{|c|c|c|c|c|c|}
\hline & & 1 & 2 & 3 & $\begin{array}{l}\text { group means' } z \\
\text { signt. at } p<.01\end{array}$ \\
\hline $\begin{array}{l}\text { Number of } \\
\text { business } \\
\text { nights/yr }\end{array}$ & $\begin{array}{r}\mathrm{N} \\
\text { mean } \\
\mathbf{s . d .} \\
\text { median } \\
\text { mode }\end{array}$ & $\begin{array}{r}139 \\
22.46 \\
(37.09) \\
10 \\
0\end{array}$ & $\begin{array}{c}102 \\
11.09 \\
(16.23) \\
5 \\
0\end{array}$ & $\begin{array}{r}35 \\
8.03 \\
(20.31) \\
3 \\
0\end{array}$ & $\begin{array}{l}1,2 \\
1,3\end{array}$ \\
\hline $\begin{array}{l}\text { Number of } \\
\text { leisure } \\
\text { nights/yr }\end{array}$ & $\begin{array}{r}\mathrm{N} \\
\text { mean } \\
\mathbf{s . d .} \\
\text { median } \\
\text { mode }\end{array}$ & $\begin{array}{r}248 \\
15.78 \\
(14.19) \\
12 \\
10\end{array}$ & $\begin{array}{r}251 \\
14.22 \\
(14.44) \\
10 \\
10\end{array}$ & $\begin{array}{c}103 \\
15.22 \\
(14.12) \\
12 \\
10\end{array}$ & \\
\hline $\begin{array}{l}\text { Number of } \\
\text { trips } \\
\text { this stay }\end{array}$ & $\begin{array}{r}\mathrm{N} \\
\text { mean } \\
\mathbf{s . d .} \\
\text { median } \\
\text { mode }\end{array}$ & $\begin{array}{c}320 \\
2.20 \\
(1.40) \\
2 \\
2\end{array}$ & $\begin{array}{c}356 \\
1.81 \\
(1.23) \\
1 \\
1\end{array}$ & $\begin{array}{c}173 \\
1.58 \\
(0.95) \\
1 \\
1\end{array}$ & $\begin{array}{l}1,2 \\
1,3\end{array}$ \\
\hline $\begin{array}{l}\text { Number of } \\
\text { days } \\
\text { stayed }\end{array}$ & $\begin{array}{r}\mathrm{N} \\
\text { mean } \\
\mathbf{s . d .} \\
\text { median } \\
\text { mode }\end{array}$ & $\begin{array}{c}310 \\
2.17 \\
(1.60) \\
2 \\
1\end{array}$ & $\begin{array}{c}348 \\
1.67 \\
(1.32) \\
1 \\
1\end{array}$ & $\begin{array}{r}164 \\
1.45 \\
(1.20) \\
1 \\
1\end{array}$ & $\begin{array}{l}1,2 \\
1,3\end{array}$ \\
\hline $\begin{array}{l}\text { Room } \\
\text { Price } \\
\text { (\$) }\end{array}$ & $\begin{array}{r}\mathrm{N} \\
\text { mean } \\
\mathbf{s . d .} \\
\text { median } \\
\text { mode }\end{array}$ & $\begin{array}{r}280 \\
66.22 \\
(28.64) \\
60 \\
50\end{array}$ & $\begin{array}{r}314 \\
51.42 \\
(20.78) \\
46.5 \\
40\end{array}$ & $\begin{array}{r}154 \\
35.34 \\
(13.68) \\
32 \\
35\end{array}$ & all \\
\hline $\begin{array}{l}\text { Percent } \\
\text { resp. } \\
\text { switching }\end{array}$ & $\begin{array}{r}\mathrm{N} \\
\text { mean } \\
\mathbf{s . d .} \\
\text { median } \\
\text { mode }\end{array}$ & $\begin{array}{c}321 \\
0.51 \\
(0.50) \\
1 \\
1\end{array}$ & $\begin{array}{c}356 \\
0.51 \\
(0.50) \\
1 \\
1\end{array}$ & $\begin{array}{c}173 \\
0.23 \\
(0.42) \\
0 \\
0\end{array}$ & $\begin{array}{l}1,3 \\
2,3\end{array}$ \\
\hline $\begin{array}{l}\text { Overall } \\
\text { satist. } \\
(1-10)\end{array}$ & $\begin{array}{r}\mathrm{N} \\
\text { mean } \\
\mathbf{s . d .} \\
\text { median } \\
\text { mode }\end{array}$ & $\begin{array}{c}318 \\
7.58 \\
(2.02) \\
8 \\
8\end{array}$ & $\begin{array}{r}354 \\
7.24 \\
(2.12) \\
8 \\
8\end{array}$ & $\begin{array}{r}169 \\
7.48 \\
(1.89) \\
8 \\
8\end{array}$ & \\
\hline $\begin{array}{l}\text { Satisf. } \\
\text { with } \\
\text { value } \\
(1-10)\end{array}$ & $\begin{array}{r}N \\
\text { mean } \\
\text { s.d. } \\
\text { median } \\
\text { mode }\end{array}$ & $\begin{array}{c}140 \\
7.07 \\
(2.58) \\
8 \\
10\end{array}$ & $\begin{array}{c}186 \\
7.00 \\
(2.27) \\
7.5 \\
8\end{array}$ & $\begin{array}{c}79 \\
8.13 \\
(1.84) \\
9 \\
10\end{array}$ & $\begin{array}{l}1,3 \\
2,3\end{array}$ \\
\hline
\end{tabular}




\section{APPENDIX}

\section{Latent class analysis of lodging chain switching behavior}

Switching Data. The data were recorded by D. K. Shifflet \& Associates from their 1989 survey of the NFO panel of households about their recent (i.eM most recent three months) choices of overnight accommodations. On the survey questionnaire, respondents list names of lodging chains, number of nights stayed, number of trips taken, room prices paid, purpose of travel, and other measures relevant to their recent travel behavior. By ordering the lodging stays by date, it is possible for us to count, for those travellers who reported more than one stay, the number of two-stay "switches” between the top ten share lodging chains. Separately for (primarily) business stays and (primarily) leisure stays, we constructed matrices, shown in Table Al, of switching frequencies for these chains.

Starting values of latent class segments and within-class purchase probabilities. Derivation of latent clustering solutions usually requires the analyst to input starting values (guesses) of all parameters. The parameters in this case are purchase probabilities (shares of the market) represented by each latent class of customers and, within each latent class, purchase probabilities of brands for customers within that class.

Based on early work in decomposing consumer-based competitive brand measures (e.g., Fraser and Bradford 1983), more recent researchers in latent class analysis have tended to use exploratory principal-components factor analysis of the observed switching proportions to derive initial guesses for these starting values (e.g., Jain et al. 1990). Since principal components analysis requires a symmetric, positive, semi-definite matrix for input, we averaged the upper and lower off-diagonals and divided all cells by the total number of purchases reported in the matrix to get matrices of symmetric switching proportions. A Pearson's chi-square test of 
differences between the resulting symmetric matrices and their original counteiparts is not significant at any reasonable level, implying that the averaging approach used is statistically acceptable.

Principal component analyses which treat the switching proportions as covariances (but generate solutions based on the implied correlation matrices) were run for two, three, four and five components for each of the switching matrices (business and leisure markets). A maximum of five components was chosen primarily because it corresponded to a scree test of eigenvalues. However, as explained below, this cutoff was low enough to lead us to an optimum final latent class solution for each market.

After varimax rotation, "high” loadings within each component should, in principle, reflect brands among which there is more switching by a segment of customers "represented" by that component (see Jain et al. for the rationale behind this interpretation). This, in effect, produces a set of "brand/segments," which can be interpreted as segments of customers who tend to patronize a small group of brands. Since the component loadings yield only an initial estimate of brand partitions, however, it is necessary to run a latent class analysis to satisfy the true notions of segment membership probabilities and within-segment purchase probabilities.

Interpretation of which loadings are "high" depends on the cutoff values selected by the analyst In our case, we selected a "liberal" value (.25) for which we could confidently say that the particular brands identified by these loadings have some chance of competing across brand/segment partitions. The selection of this starting value was based on the distribution of the absolute value of the loadings from all of the principal component analyses initially run. This distribution is portrayed in Figure 1. 
It can be seen from Figure 1 that an "elbow" drop in the distribution occurs at .25. This type of visual drop is often employed in the analysis of eigenvalues to determine a useful number of factors to extract. The interpretation behind an analogous "elbow" tool here is that, as in the typical scree test, no more information is gained by going to a higher cutoff, while a potential loss of information occurs by going to a lower cutoff (in the sense of accepting as valid more of the lower-end, potentially spurious loadings). Hence, we used .25 as the loading cutoff to identify in which multiple partitions brands might compete.

To determine the starting values for the latent class probabilities we first constructed a temporary mutually exclusive partitioning of brands based on the maximum loading of each brand across the components. Starting values for the latent class probabilities were then set equal to the summed market shares of brands within each resulting brand/segment.

The next step was to estimate starting values for the within-class brand probabilities. First, all brands with loadings less than .25 were "forced" to have within-class probabilities of zero. (The latter selection is important for determining what effect restrictions, which are generally required for model identification in this type of analysis, might have on the terminal solution. In our case, the appealing "face” value of the results support the use of this cutoff criteria.) Starting values for the within-class probabilities for each brand, within its component(s), were then set equal to the relative proportion of loading to the sum of the nonnegative component loadings. The component loadings used to generate starting values for the final latent class analysis for each market are shown in Table A2.

Selecting the latent class solutions from among the two, three, four and five class solutions for each market. Several statistical and judgmental criteria can be used to select the number of latent classes for this type of data (see Grover and Srinivasan 1987, Jain et al. 1990). 
In our case, we were first interested in choosing solutions which were not sensitive to moderate changes in the starting values (see McCutcheon 1987 for a discussion of this critical issue). This is true (despite our care in selecting initial starting values) because several of the cells of the switching matrices have zero frequency. Under these conditions, it is more possible for the likelihood function to become nonconcave, the greater the distance of the starting values from the global maximum (see Clogg and Eliason 1987).

Upon perturbing the starting values initially chosen, we found that the four-segment solution for the business market and the three-segment solution for the leisure market provided the largest number of segments while still providing convergence to the same final parameter estimates. We then chose, from among these "feasible” latent class solutions, one for each market which provided the minimum values of Akaike’s Information Criterion (AIC; see Akaike 1974)-a measure of the magnitude of the final likelihood function penalized for the number of parameters used. The values of AIC and indications of sensitivity to starting values are shown in Table A3.

Assignment of respondent lodging stays to latent classes and generation of summary statistics by latent class. It was necessary, for each latent class, to summarize lodging stay characteristics and respondent background measures associated with each stay represented in the switching matrices for each market. Because the observations classified into frequency cells of a brand switching matrix are actually "stay-pairs" -that is, the number of pairwise switches from one lodging brand to another were counted for each cell-posterior assignment of observations to the most "likely" latent class are made by cell. This means that each stay-pair is assigned to one of the latent classes on the basis of which cell in the switching matrix it belongs to. If an observed stay-pair is Holiday Inn-Best Western, for example, and the most likely latent class 
probability for this cell is that of latent class number two, then all observations within that cell are assigned to latent class number two.

The rule for assignment is the Bayesian posterior probability (see McCutcheon 1987):

$$
\mathrm{P}(\text { Class=I|cell i j })=P(\mathrm{i}, \mathrm{j}, \mathrm{I}) / \Sigma \mathrm{P}(\mathrm{i}, \mathrm{j}, \mathrm{K})
$$

For all latent classes $\mathrm{K}$ and switching frequencies $\mathrm{i}$ j. Once the stay-pairs are assigned to latent classes, all characteristics of the current stay in the stay-pair can be summarized statistically.

The advantage of this approach is that stays are examined individually and the sample results thus summarize information on stays rather than on buyers (the only exception we make is in the reported number of business and leisure stay-nights per year, which are reported for buyers who are for this purpose only assigned to latent classes on the basis of their most recent stay.) Thus we allow buyers to belong to more than one latent class, depending on which of their stay-pairs are assigned to which latent classes. This approach corresponds to recent segmentation theory which holds that buyers should not necessarily be assigned to mutually exclusive segments (see Kamakura and Russell 1989). The disadvantage is that we must assume that purchases by individuals are independent over stay occasions. As it turns out, $62 \%$ of businessstay respondents and $73 \%$ of leisure-stay respondents used to construct the switching matrices do not report more than the minimum of two stays, so the assignment of stays, as opposed to respondents, to latent classes may not substantially affect the summary statistics. However, this is the only way to take advantage of all the stay information available. Evidence in support of an assumption of independence of with- in-respondent stays currently awaits future research. 
Summary. The procedure used to determine which latent class solutions to select can be summarized as follows:

1. The switching matrix is input to a principal components factor analysis.

2. The component loadings are used to estimate starting values of the parameters for the latent class analysis.

3. The latent class solutions considered are restricted to those which do not exhibit sensitivity to starting values.

4. From among the solutions considered, we choose the one with the minimum AIC.

5. Using the chosen latent class solution, cells in the switching frequency matrix are assigned to latent classes on the basis of their Bayesian posterior probability for those classes. Summary statistics can then be generated for each class and for each type of market. 
Table A1. Switching matrices derived from repeat lodging purchases in Shifflet \&

Associates survey data.

\section{Business market:

Holiday Inn
Best Westem
Days Inns
Marriott
Hilton
Motel 6
Sheraton
Ramada
Super 8
Hyatt

Leisure market:

Holiday Inn
Best Western
Days Inns
Marriott
Hilton
Motel 6
Sheraton
Ramada
Super 8
Hyatt

$\begin{array}{rrrrrrrrrr}385 & 27 & 13 & 26 & 25 & 7 & 15 & 22 & 1 & 11 \\ 26 & 77 & 6 & 3 & 2 & 3 & 2 & 8 & 3 & 3 \\ 17 & 6 & 50 & 4 & 1 & 1 & 0 & 3 & 2 & 2 \\ 38 & 4 & 4 & 112 & 21 & 0 & 13 & 6 & 1 & 19 \\ 29 & 5 & 4 & 25 & 57 & 0 & 11 & 1 & 1 & 6 \\ 3 & 7 & 1 & 0 & 1 & 50 & 0 & 1 & 3 & 0 \\ 23 & 4 & 3 & 7 & 14 & 0 & 43 & 7 & 0 & 6 \\ 16 & 2 & 6 & 5 & 2 & 0 & 3 & 28 & 2 & 1 \\ 5 & 6 & 4 & 1 & 0 & 3 & 0 & 2 & 32 & 0 \\ 15 & 2 & 0 & 14 & 10 & 0 & 4 & 2 & 0 & 18\end{array}$

$\begin{array}{rrrrrrrrrr}126 & 24 & 23 & 5 & 6 & 4 & 4 & 10 & 1 & 0 \\ 23 & 110 & 16 & 1 & 2 & 9 & 4 & 7 & 6 & 0 \\ 31 & 11 & 61 & 4 & 5 & 2 & 3 & 2 & 4 & 1 \\ 8 & 3 & 1 & 13 & 2 & 0 & 1 & 2 & 0 & 2 \\ 6 & 4 & 3 & 6 & 11 & 0 & 4 & 1 & 0 & 1 \\ 5 & 11 & 5 & 1 & 1 & 110 & 1 & 1 & 9 & 0 \\ 10 & 2 & 7 & 1 & 5 & 1 & 7 & 3 & 0 & 3 \\ 10 & 7 & 5 & 3 & 4 & 4 & 1 & 10 & 1 & 0 \\ 5 & 11 & 2 & 0 & 1 & 6 & 0 & 1 & 45 & 0 \\ 2 & 0 & 2 & 3 & 0 & 0 & 2 & 0 & 0 & 2\end{array}$


Table A2. Principal component factor loadings derived from switching matrices.

Market:

Component

Business only

$\begin{array}{rrrr}1 & 2 & 3 & 4 \\ 0.03 & 0.69 & 0.24 & -0.04 \\ -0.11 & 0.51 & 0.16 & 0.33 \\ 0.31 & 0.71 & -0.12 & -0.00 \\ 0.35 & -0.17 & 0.72 & 0.04 \\ 0.29 & 0.20 & 0.61 & -0.06 \\ 0.01 & -0.00 & 0.06 & 0.71 \\ 0.78 & 0.33 & 0.20 & -0.02 \\ -0.17 & 0.38 & 0.68 & 0.07 \\ 0.03 & 0.07 & -0.06 & 0.73 \\ 0.91 & -0.08 & 0.14 & 0.04\end{array}$

Leisure only

\begin{tabular}{rrr} 
& \multicolumn{2}{c}{ Component } \\
1 & 2 & 3 \\
0.30 & 0.54 & 0.03 \\
0.03 & 0.44 & 0.39 \\
-0.02 & 0.51 & 0.14 \\
0.72 & 0.02 & 0.04 \\
0.68 & 0.05 & 0.02 \\
0.05 & -0.10 & 0.75 \\
0.45 & 0.28 & -0.16 \\
0.02 & 0.71 & -0.10 \\
-0.04 & 0.15 & 0.59 \\
0.71 & 0.01 & 0.04
\end{tabular}


Table A3. Latent class solutions by sensitivity to starting values and Akaike's information criteria (AIC).

$\begin{array}{lcclc} & \begin{array}{l}\text { Number of } \\ \text { classes }\end{array} & \begin{array}{l}\text { Number of } \\ \text { parameters }\end{array} & \text { AIC } & \text { Sensitive? } \\ \text { Business market: } & 2 & 10 & 5387 & \text { No } \\ & 3 & 12 & 4716 & \text { No } \\ \text { Leisure market: } & 4 & 16 & 4701^{\circ} & \text { No } \\ & 5 & 17 & 4769 & \text { Yes } \\ \text {-Solution chosen } & 2 & 11 & 3477 & \text { No } \\ & 3 & 12 & 2901^{\circ} & \text { No } \\ & 4 & 13 & 2950 & \text { Yes } \\ & 5 & 12 & 3175 & \text { Yes }\end{array}$


Figure 1. Distribution of absolute loading values used to compute starting values.

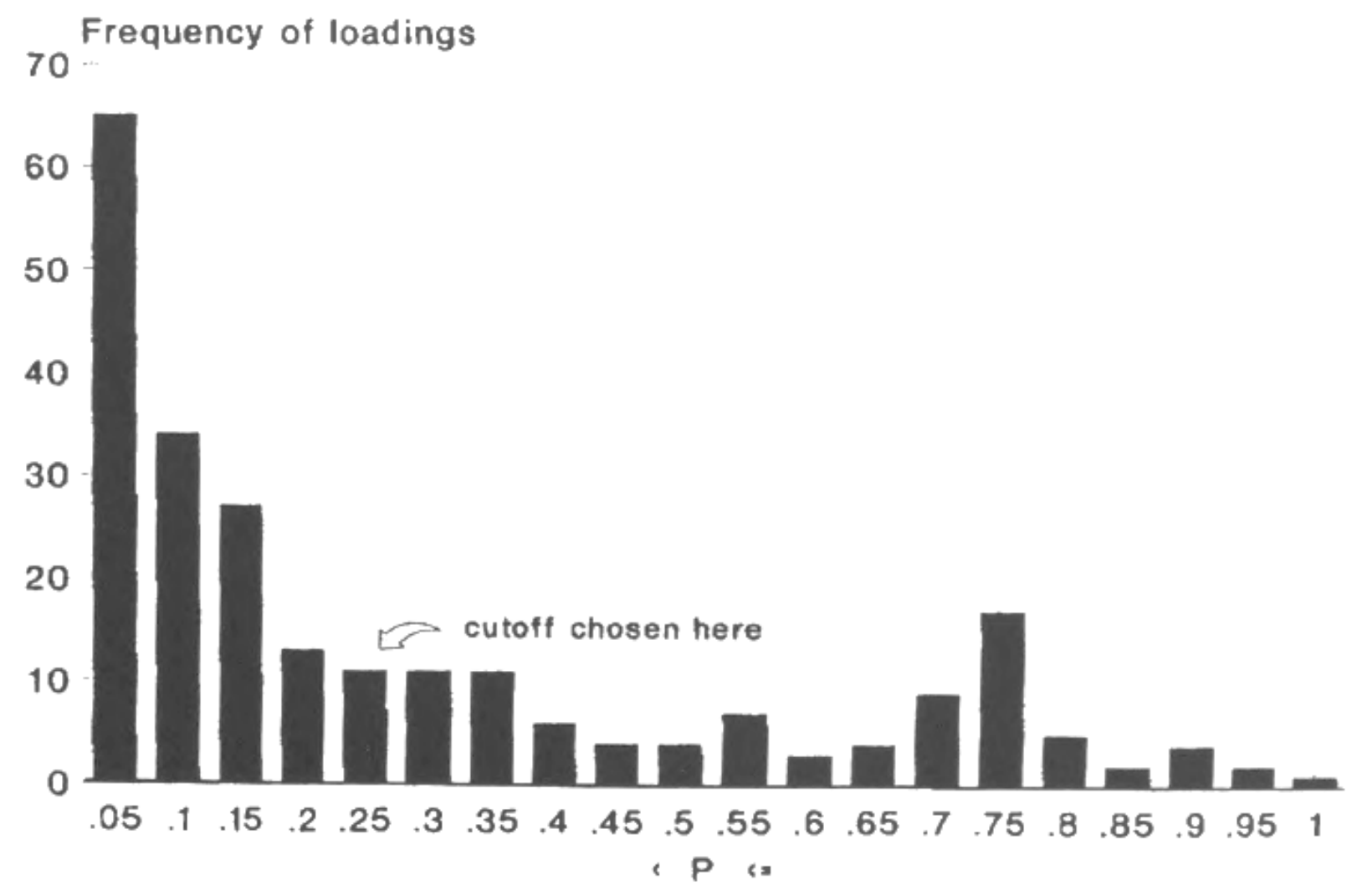

